\title{
Consistent Output Series for the Antebellum and Postbellum Periods: Issues and Preliminary Results
}

\author{
Charles W. Calomiris and Christopher Hanes
}

Existing output series that cover both the antebellum and postbellum periods are inconsistent and unsuitable for comparing cyclical patterns across the nineteenth century. More consistent data show that output in cyclically sensitive sectors was no less, and probably more, volatile before the War Between the States than after it.

$\mathbf{T}$ ime-series data on aggregate output can reveal historical changes in the characteristics of business cycles: patterns in output movements and relations between output and financial events or other macroeconomic variables such as price levels. Associating changes in cyclical patterns with developments in economic structure and institutions is an important job for economic historians and may bear on issues in macroeconomic theory. Comparisons across historical periods require series that are consistent across those periods, constructed in the same way from the same kinds of information. Otherwise one may mistake incomparabilities in the data for changes over time in economic behavior. Christina Romer and others have constructed output series for postbellum decades-that is, years between the War Between the States and World War I-designed to be consistent with postwar twentieth-century series and allow comparison between late-nineteenthcentury and postwar cycles. ${ }^{1}$

But some of the most important changes in economic structure took place before or shortly into the postbellum period. By the 1880 s the more developed regions of the United States had already undergone their industrial revolution. Firms supplied concentrated markets through reliable distribution networks. ${ }^{2}$ Establishments (plants) were already large; Anthony O'Brien shows that "almost two-thirds of the increase in factory size [employment] that was to take place between

The Journal of Economic History, Vol. 54, No. 2 (June 1994). () The Economic History Association. All rights reserved. ISSN 0022-0507.

Charles W. Calomiris is Associate Professor, Department of Finance, University of Illinois, 1206 S. 6th St., Champaign, Illinois 61820, and Faculty Research Fellow, National Bureau of Economic Research. Christopher Hanes is Assistant Professor, Department of Economics, University of Pennsylvania, 3718 Locust Walk, Philadelphia, Pennsylvania 19104.

Thanks to Thomas Senior Berry, John James, and especially Robert Gallman for advice and data.

${ }^{1}$ Romer, "Is the Stabilization"; Balke and Gordon, "Estimation of Prewar"; Miron and Romer, "A New Monthly Index."

${ }^{2}$ Chandler, The Visible Hand. 
1869 and 1929 had occurred by $1889 .{ }^{, 3}$ Thus, the effects on business cycles of the rise of large-scale industry may show up most clearly in series that span the nineteenth century, covering both antebellum and postbellum periods.

Rare attempts to push back the frontier of macroeconomic history, like those of John James, have been hampered by a lack of consistent antebellum-postbellum data. ${ }^{4}$ The standard NBER chronology of peaks and troughs is based on different information and criteria before and after $1854 .^{5}$ Robert Gallman's unpublished annual series on real GNP begins in 1834 and has been used to compare antebellum with postbellum and even twentieth-century cycles. But the briefest glance at Gallman's notes reveals that the information behind his annual "interpolations" between census-year benchmarks varies enormously from decade to decade. The antebellum data are much scantier than those for the 1870 s and 1880 s, which are in turn less reliable than those for the 1890 s. $^{6}$ Indeed, Gallman has refrained from publishing the series precisely because he does not trust its year-to-year movements. Thomas Berry's annual real GNP series is derived from a nominal GNP series using deflators that were "smoothed slightly so as to yield GNP series over 1789-1889 . . . with comparable volatility before and after 1889." "7 The nominal GNP series is in turn based on a mix of nominal and real series, with many components absent before the $1860 \mathrm{~s}^{8}$

We have begun a project to create a peak-trough chronology and an output series covering both antebellum and postbellum years through 1914 , consistent and comparable throughout. This paper discusses some issues associated with the construction of the output series and presents some preliminary answers to one of the questions the series will be designed to answer: Did the amplitude of business cycles change from the antebellum to the postbellum period?

As John James found, the Gallman series suggests that "There was a substantial increase in the degree of business cycle severity of economic fluctuations in the United States over the nineteenth century."9 This can be seen in Table 1, which shows statistics on the Gallman series' deviations from two different trends: simple quadratic time trends (time and time squared), separate for each period, and the Hodrick-Prescott

${ }^{3}$ O'Brien, "Factory Size," p. 645.

4 James, "The Stability of the 19th-Century" and "Changes in Economic Instability."

5 Moore and Zarnowitz, "Development and Role," p. 755.

6 The series is described in Gallman, "Gross National Product." Examples of its use include James, "Stability of the 19th-Century" and "Changes in Economic Instability"; Temin, The Jacksonian Economy.

7 Berry, "Production and Population," p. 6.

8 Berry, "Estimated Annual Variations," table 3.

9 James, "Changes in Economic Instability," p. 710. 
TABLE 1

VOLATILITY OF EXISTING SERIES

Standard deviation of deviation from trend in $\log$

\begin{tabular}{cccccc}
\hline \hline & \multicolumn{2}{c}{ Gallman Real GNP } & & \multicolumn{2}{c}{ Berry Real GNP } \\
\cline { 2 - 3 } \cline { 6 - 6 } Period & $\begin{array}{c}\text { Quadratic } \\
\text { Time }\end{array}$ & $\begin{array}{c}\text { Hodrick- } \\
\text { Prescott }\end{array}$ & & $\begin{array}{c}\text { Quadratic } \\
\text { Time }\end{array}$ & $\begin{array}{c}\text { Hodrick- } \\
\text { Prescott }\end{array}$ \\
\hline $1840-1859$ & 0.0365 & 0.0361 & & 0.0344 & 0.0354 \\
$1870-1914$ & 0.0553 & 0.0461 & & 0.0396 & 0.0383 \\
$1870-1890$ & 0.0519 & 0.0442 & & 0.0276 & 0.0276 \\
$1891-1914$ & 0.0572 & 0.0469 & & 0.0483 & 0.0464 \\
\hline
\end{tabular}

Sources: Gallman series provided by Robert Gallman. Berry series from Berry, "Production and Population."

trend. ${ }^{10}$ The antebellum period is restricted to its last two decades because the data relied on below will not allow us to say much about years before 1840. Consistent with James's observation, the Gallman series appears more volatile over 1870 to 1914 than over 1840 to 1859 . Dividing the postbellum period at 1890, the period from 1891 to 1914 appears more volatile than 1870 to 1890 , but both appear more volatile than 1840 to 1860 . Table 1 also shows statistics for the Berry real GNP series. The Berry series is only slightly more volatile over 1870 to 1914 than over 1840 to 1859 and is less volatile over 1870 to 1890 than over 1840 to 1859.

What answer do we get from more consistent output series? That depends on one's definition of "output," in a way that has been largely ignored by the literature following Romer.

\section{WHAT DO WE MEAN BY “OUTPUT”? GNP VERSUS INDUSTRIAL PRODUCTION}

In 1950 Simon Kuznets observed that because sectors vary in their sensitivity to business cycles, the cyclical behavior of aggregate output and employment might change over time as a result of shifts in the relative importance of different sectors, even if "there are no marked secular shifts within each sector in responsiveness to business cycles. . . . For example, a decline in the weight of agriculture combined with a lack of responsiveness of agricultural output to business cycles would mean, other conditions being equal, a widening of business cycle

${ }^{10}$ This is described in Kydland and Prescott, "Business Cycles." If $x$ is the time-series variable, the trend $\hat{x}$ is defined as the solution to

$$
\min _{t_{t}} \sum_{t_{0}}^{t_{1}}\left(x_{t}-\hat{x}_{t}\right)^{2}+\lambda \sum_{t_{0}+1}^{t_{1}-1}\left[\left(\hat{x}_{t+1}-\hat{x}_{t}\right)-\left(\hat{x}_{t}-\hat{x}_{t-1}\right)\right]^{2}
$$

with $\lambda$ set at $\mathbf{4 0 0}$ for annual data. 
amplitudes."11 Wesley Mitchell, George Burns, and other National Bureau researchers had shown agriculture to be uniquely acyclical: "the basic industry of growing crops does not expand and contract in unison with mining, manufacturing, trading, transportation, and finance." "In no other great industry for which we have records are the cyclical fluctuations so irregularly related to business cycles as in crop husbandry." 12 Farm output and employment "undergo cyclical movements, but they have little or no relation to business cycles."13 This had been especially obvious during the Great Depression. From 1930 to 1932 employment fell in every major nonagricultural sector, including trade and services; aggregate employment fell by 14 percent. Meanwhile farm employment increased by 3 percent. ${ }^{14}$ But it had also been true in earlier decades. In his study of the period between the War Between the States and World War I, Edwin Frickey found "agricultural production patterns traced out short-term fluctuations bearing little resemblance to those for other major production groups. The causal relationships between the agricultural and non-agricultural groups certainly did not express themselves in the form of any simple correlation." 15 That is not to say that agricultural incomes are acyclical. There may be cyclical patterns in the relative price of farm output.

Table 2 illustrates these points for the postbellum and twentiethcentury postwar periods, with regressions of deviation from trend in real GNP on deviation from trend in sectoral employment and output indices (all in logs). For the postbellum period we use Frickey's indices of output in manufacturing and transportation and both the Romer and the Balke and Gordon series on real GNP. The Frickey manufacturing index runs from 1861 through 1914 but is not consistent until the 1870s (several of its component series are missing before that decade). ${ }^{16}$ There are no reliable annual data on employment for most of the postbellum period. For the postwar period manufacturing is represented by the Federal Reserve Board Index of Materials production, which is comparable to the Frickey manufacturing index. ${ }^{17}$ For employment the sample ends with 1980 because the farm data were not collected from 1981 through 1984.

The first part of the table shows postwar patterns. Regressing real GNP on manufacturing production gives a significantly positive coefficient. For agricultural output the coefficient is zero and insignificant. Employment levels in all nonagricultural sectors are strongly procycli-

11 Kuznets, “Comment” on Schumpeter, p. 159.

12 Mitchell, What Happens, pp. 56, 58.

13 Burns, "Mitchell," pp. 7, 8.

14 U.S. Department of Commerce, Historical Statistics. Nonagricultural Sectoral Employment Series D127-141, Total Employment Series D5, Farm Employment Series K174.

15 Frickey, Economic Fluctuations, p. 229.

16 Frickey, Production in the United States.

${ }^{17}$ Romer, "Is the Stabilization." 


\section{TABLE 2}

AGRICULTURE AND BUSINESS CYCLES

Variables are deviations of logs from Hodrick-Prescott trend $(t$-statistics in parentheses)

\begin{tabular}{|c|c|c|}
\hline \multicolumn{3}{|c|}{ I. Post-1947 } \\
\hline \multicolumn{3}{|c|}{ Manufacturing } \\
\hline Materials production & 0.4312 & $(12.831)$ \\
\hline \multicolumn{3}{|l|}{ Agriculture } \\
\hline Crops and livestock & -0.0291 & $(-0.275)$ \\
\hline Crops only & -0.0363 & $(-0.493)$ \\
\hline \multicolumn{3}{|c|}{ Employment 1947-1980 - Real GNP regressed on employment } \\
\hline All nonfarm & 1.0091 & (8.159) \\
\hline Services & 1.2440 & (4.552) \\
\hline Other than services & 0.6741 & (10.147) \\
\hline Manufacturing only & 0.6407 & (10.262) \\
\hline All farm & -0.3896 & $(-3.046)$ \\
\hline Hired only & -0.2522 & $(-3.823)$ \\
\hline \multicolumn{3}{|c|}{ II. Pre-1914 } \\
\hline \multicolumn{3}{|c|}{ Output 1869-1914 - Real GNP regressed on output indices } \\
\hline \multicolumn{3}{|c|}{ Romer GNP } \\
\hline Manufacturing (Frickey) & 0.2311 & (4.847) \\
\hline Transportation (Frickey) & 0.2203 & (3.147) \\
\hline Agriculture, crops only & 0.0076 & (0.111) \\
\hline \multicolumn{3}{|l|}{ Balke and Gordon GNP } \\
\hline Manufacturing (Frickey) & 0.4136 & (7.397) \\
\hline Transportation (Frickey) & 0.4918 & (6.053) \\
\hline Agriculture, crops only & 0.0562 & $(0.582)$ \\
\hline \multicolumn{3}{|c|}{ Frickey manufacturing index regressed on output indices } \\
\hline Transportation (Frickey) & 1.0651 & (9.157) \\
\hline Agriculture, crops only & 0.0357 & (0.204) \\
\hline
\end{tabular}

Sources: Postwar real GNP, 1982 dollars, from U.S. Council of Economic Advisers. Postbellum GNP from Romer, "Prewar Business Cycle," and Balke and Gordon, "Estimation of Prewar." Postwar manufacturing and output indices from U.S. Council of Economic Advisers. Employment from U.S. Bureau of Labor Statistics. Postbellum farm output index from U.S. Department of Agriculture, "The Agricultural Situation." Frickey indices from Frickey, Production.

cal, but agricultural employment is countercyclical. The second part of the table shows results for the postbellum period. Regressing either real GNP series on either the manufacturing or transportation index gives a significantly positive coefficient. Regressing output on the crop index gives a much smaller and insignificant coefficient. The Frickey manufacturing index is closely correlated with the transportation index but not with the crop index.

The fact that agricultural fluctuations are independent of business cycles has not received enough attention in the literature on macroeconomic history. DeLong and Summers argue that cyclical volatility might have fallen over time because "agriculture, which is notoriously unstable, has shrunk rapidly as a share of GNP." 18 Romer treats volatility of

${ }^{18}$ DeLong and Summers, "The Changing Cyclical Variability," p. 685. 
industrial production and real GNP including agriculture as more or less equivalent indicators of business cycle severity. ${ }^{19}$ Whether or not this is justifiable for comparisons between periods since the $1870 \mathrm{~s}$, it is probably not for antebellum and postbellum periods. The shift out of agriculture was especially rapid across the nineteenth century. From 1840 to 1900 farm gross product (output value minus value of inputs excluding capital depreciation) fell from about one-half of GNP to about one-fifth. Agricultural employment fell from 63 percent of total employment to 40 percent. Meanwhile the share of manufacturing in GNP or employment doubled. ${ }^{20}$

We intend to construct a consistent antebellum-postbellum index of industrial production along the lines of the postbellum Frickey manufacturing index and twentieth-century Federal Reserve Board production indices. We believe it is impossible to construct an adequately consistent series for real GNP, if only because antebellum data on many important components of farm production are fragmentary or missing altogether.

\section{DATA FOR A CONSISTENT OUTPUT SERIES}

Our first job was to collect all data that began by 1840 , ran through the postbellum period, were consistent throughout, and indicated the movements of variables that might be correlated with industrial production. That includes quantities of just about any industrial output or input, including transportation services, and imports. ${ }^{21}$ We excluded data on prices, financial and monetary series, and nominal output values in the absence of reliable and consistent deflators. Many such series show relations to real output, but we want to use the output index to examine those relations and look for changes over time. To indicate cyclical movements the data must be observed at least annually. We found seven annual series on outputs and inputs that meet the requirements and none on a shorter frequency. Most are products of considerable research by others. We are fairly certain that no more can be constructed from primary sources. The series are listed and briefly described in the appendix. Two-pig iron production and cotton consumption-are components of the postbellum Frickey manufacturing index and may be fairly direct indicators of output in two important industries, cotton textiles and iron and steel products, which by themselves made up more than 10 percent of manufacturing employment in the 1840 s and

\footnotetext{
${ }^{19}$ See, for example, Romer, "Is the Stabilization."

${ }^{20}$ Farm gross product from Towne and Rasmussen, "Farm Gross Product." Manufacturing value-added from Gallman, "Commodity Output," p. 43. GNP from Gallman, "Gross National Product," p. 26, and Balke and Gordon, "Estimation of Prewar," table 10. Employment from Lebergott, "Labor Force," table 1.

${ }^{21}$ Mitchell found that "imports conform closely to business cycles while exports do not." Burns, "Mitchell," p. 7. See Mitchell, What Happens, for discussions and examples of other variables.
} 
$1850 \mathrm{~s}$, and slightly less than 10 percent after the war. ${ }^{22}$ There is no series on the real value of total imports, but we found consistent import volume data for 25 individual goods. ${ }^{23}$ Some are consumption goods and hence a function of aggregate income; others are inputs and are more directly linked to industrial production. The import series break in 1843, when the fiscal year shifted from ending September to ending June.

It is useful to think of each series as made up of three components: a cyclical component correlated with economywide output movements; an idiosyncratic component reflecting sector- or product-specific shocks to demand or supply; and errors in measurement, presumably independent across the series. For many of the domestic series there is reason to believe that antebellum observations contain larger errors. Import series appear about as reliable in antebellum as in postbellum years but may be subject to relatively large idiosyncratic shocks associated with changes in tariffs. It is hard to account for the effect of these on import levels. There is no index of general tariff rates. The usual proxy, aggregate tariff revenue relative to aggregate import value, varies with the composition of imports as well as changes in protection. Nineteenthcentury tariffs were a bizarre mix of nominal per-unit duties and ad valorem rates, often applied to the same good at the same time. Reclassification of a good from one schedule to another could change effective protection without any change in official rates. Legislative changes in rates or classifications were often peculiar to certain goods; sometimes rates were dropped on some goods and raised on others. ${ }^{24}$ Imports could be affected by expectations of rate changes that had not yet taken place. Consider wool in the 1890s, described by Taussig:

The [duty-] free admission of wool in 1894 and the re-imposition of duties three years later necessarily caused great shifts. In the year just before the act of 1894 , when it was almost certain that wool would become [duty-] free, imports naturally shrank to almost nothing. They then rose abruptly as soon as the abolition of the duty went into effect. Again, after the election of McKinley in the autumn of 1896 it became in turn almost certain that the duty would be restored. Consequently during the fiscal year 1896-1897, imports were rushed in from every possible quarter while wool was still free. They then fell abruptly after the passage of the tariff act of 1897 . . . . Not until 1900 were the effects of this abnormal situation out of the way. ${ }^{25}$

A wool import series would probably give a fairly inaccurate indication of woolen production, much less aggregate production, over the $1890 \mathrm{~s}$.

In this paper we restrict our focus to a couple of imports for which changes in tariffs and substitution between domestic and foreign sup-

${ }^{22}$ Lebergott, "Labor Force," table 1.

${ }^{23}$ Total nominal value deflated by a price index would be suitable only if we had a consistently constructed import price index and the composition of imports were acyclical or held a consistent cyclical pattern between the antebellum and postbellum periods.

${ }^{24}$ Taussig, Tariff History, gives many examples.

${ }^{25}$ Taussig, Some Aspects, p. 299. 
TABLE 3

VOLATILITY IN CONSISTENT ANTEBELLUM-POSTBELLUM SERIES

(Standard deviation of deviation from trend)

\begin{tabular}{|c|c|c|c|c|c|}
\hline & \multicolumn{3}{|c|}{$\begin{array}{l}\text { I. Individual Series } \\
\text { Quadratic }\end{array}$} & \multicolumn{2}{|c|}{ Hodrick-Prescott } \\
\hline & $1821-1859$ & $1840-1859^{a}$ & $1870-1914$ & $1840-1859$ & $1870-1914$ \\
\hline Anthracite coal & & 0.0609 & 0.1059 & 0.0925 & 0.0981 \\
\hline Bituminous coal & & 0.0810 & 0.0797 & 0.0831 & 0.0763 \\
\hline NY Canal traffic & & 0.1720 & 0.0985 & 0.1699 & 0.0924 \\
\hline Erie Canal traffic & & 0.1571 & 0.1499 & 0.1679 & 0.1380 \\
\hline Cotton consumption & & 0.1374 & 0.0858 & 0.1378 & 0.0779 \\
\hline Lead production & & 0.1401 & 0.1601 & 0.1413 & 0.1105 \\
\hline Pig iron production & & 0.2246 & 0.1686 & 0.2214 & 0.1637 \\
\hline \multicolumn{6}{|l|}{ Imports $^{\mathrm{a}}$} \\
\hline Coffee, gross & 0.1526 & 0.1209 & 0.1199 & & \\
\hline Coffee, net & 0.1807 & 0.1340 & 0.1138 & & \\
\hline Tea, gross & 0.2422 & 0.1892 & 0.1059 & & \\
\hline Tea, net & 0.2451 & 0.2033 & 0.1153 & & \\
\hline \multicolumn{6}{|c|}{ II. Output Deviation Indices } \\
\hline & \multicolumn{2}{|c|}{$1840-1859$} & $1870-1913$ & $1870-1890$ & $1891-1913$ \\
\hline \multicolumn{6}{|l|}{ Quadratic } \\
\hline Standard deviation & \multirow{2}{*}{\multicolumn{2}{|c|}{0.1073}} & 0.0826 & 0.0875 & 0.0784 \\
\hline$R 2$ (Frickey on proxy) & & & 913 & 0.917 & 0.907 \\
\hline \multicolumn{6}{|l|}{ Hodrick-Prescott } \\
\hline Standard deviation & \multirow{2}{*}{\multicolumn{2}{|c|}{0.1072}} & \multirow{2}{*}{$\begin{array}{l}0.0780 \\
0.920\end{array}$} & 0.0821 & 0.0757 \\
\hline$R 2$ (Frickey on proxy) & & & & 0.913 & 0.930 \\
\hline
\end{tabular}

a Excludes the year 1843.

plies are not a problem: coffee and tea. Both were free of duty from 1830 through the War Between the States and again after $1872 .{ }^{26}$ These series are described in the appendix. In future work we will examine the other import series.

\section{CHANGES IN VOLATILITY IN THE SET OF CONSISTENT SERIES}

An increase in the volatility of industrial production from the antebellum to the postbellum period should show up as an increase in the volatility of each series, unless it is swamped by reductions in the volatility of idiosyncratic shocks and measurement errors. The first part of Table 3 shows volatility measures for the series over 1840 to 1859 and 1870 to 1914. The break in import data at 1843 prevents us from calculating Hodrick-Prescott trends for those series. (Quadratic trends were estimated with that year excluded from the sample.) With the exception of anthracite coal production, each of the series, including cotton consumption and pig iron production, appears less volatile in the postbellum period. The result for lead depends on the definition of

26 Taussig, Tariff History, pp. 184, 188. 
trend. Coffee and tea imports, gross or net of re-export, appear less volatile in the postbellum period than over 1840 to 1859 or a longer antebellum period, 1821 to 1859 . Thus, the behavior of the series taken one at a time suggests that output volatility decreased from the antebellum to the postbellum period.

Unfortunately, as mentioned earlier, the antebellum observations of some of the series may be more affected by measurement errors, though the fact that nearly all, including the import series, show greater antebellum volatility suggests that alone cannot account for the difference between periods. To deal with the problem directly, we can construct an index of movements in the individual series. An index might have different volatility properties from any or all of the component series because they are not independent. There are several ways to construct an index. Here we will construct a couple suitable for the question at hand.

Romer and others have used deviations from trend in the Frickey manufacturing index to indicate postbellum business cycles. Taking that as our standard, we can choose weights for deviations in the individual series so as to best reproduce deviations in the Frickey index. The weights can be taken from a regression of deviations in the Frickey index on deviations in the set of antebellum-postbellum series. Applying the estimated coefficients to the series over both the antebellum and postbellum periods gives the regression's predicted value of deviations from trend in the Frickey series for both periods-a consistent, comparable index of deviations from trend in output. This procedure is reasonable if we can believe that the relation between the set of series and manufacturing production as measured by the Frickey index was stable across the nineteenth century. We do not have enough data to check that, but we can at least make sure that the relation between the antebellum-postbellum series and the Frickey index is stable within the postbellum period. Applying the procedure to deviations from both quadratic and Hodrick-Prescott trends gives two consistent indices.

There are a couple of complications. First, we cannot use the import series in this exercise because they break at 1843. Second, the Frickey index is on a calendar-year basis, but some of the input and output series are not. The observations of a given series may be most closely correlated with the Frickey index at the leading or lagging year. We regressed the Frickey series on each series individually to see which timing was best (again, all expressed as deviation from trend). All gave the closest correlation relative to the same year except anthracite coal production, which was best at the leading year, and lead production and cotton consumption, which were best at the lagged year.

Then we regressed the Frickey index on all of the series (currentyear, lead or lag as appropriate) and applied the estimated coefficients to construct the two antebellum-postbellum indices. Figure 1 shows the 

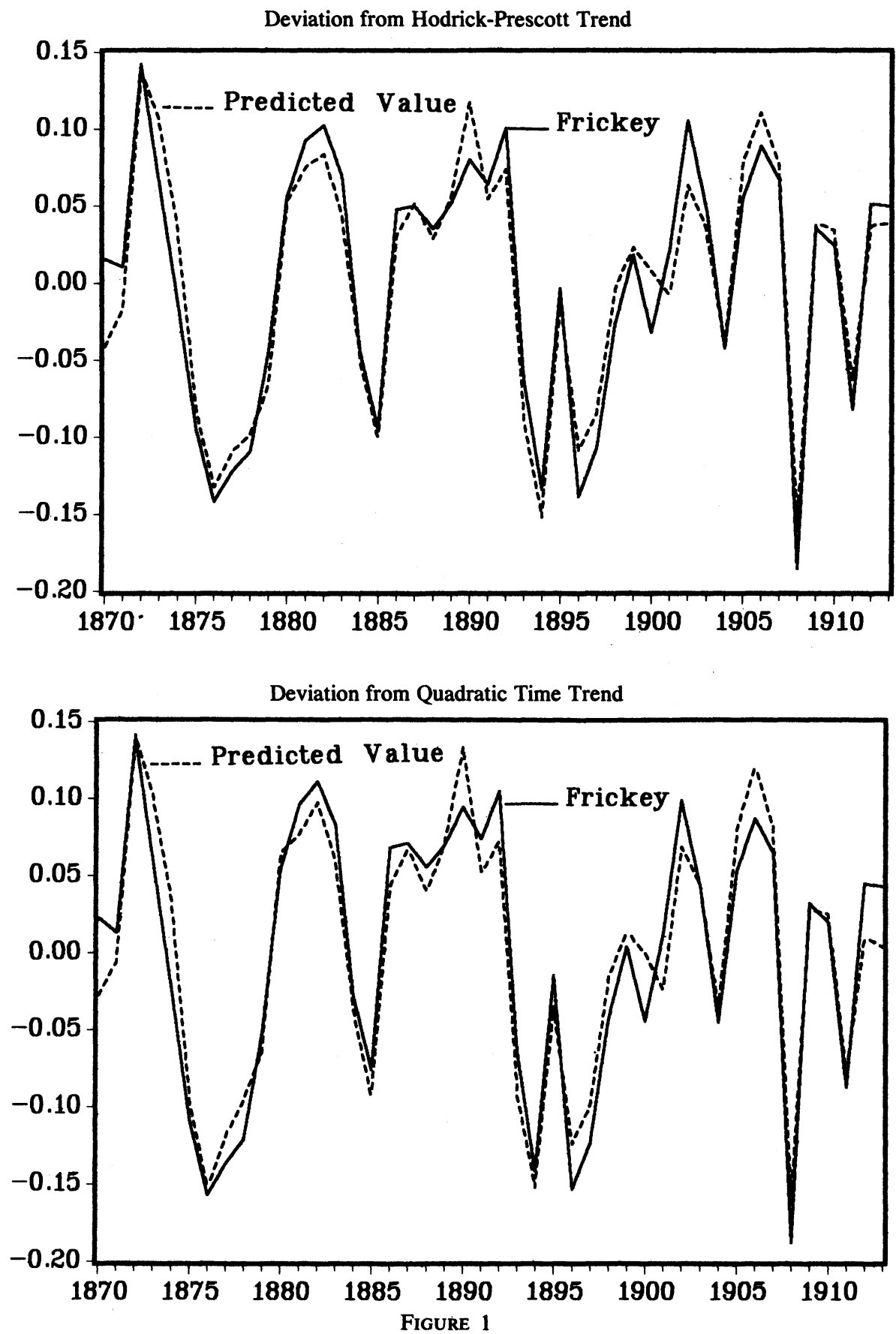

ANTEBELLUM-POSTBELLUM INDICES AND FRICKEY INDEX 1870-1913

values for these indices over postbellum years, along with the corresponding deviations from trend in the Frickey index. The two sets of series show similar peaks and troughs. The second part of Table 3 shows 

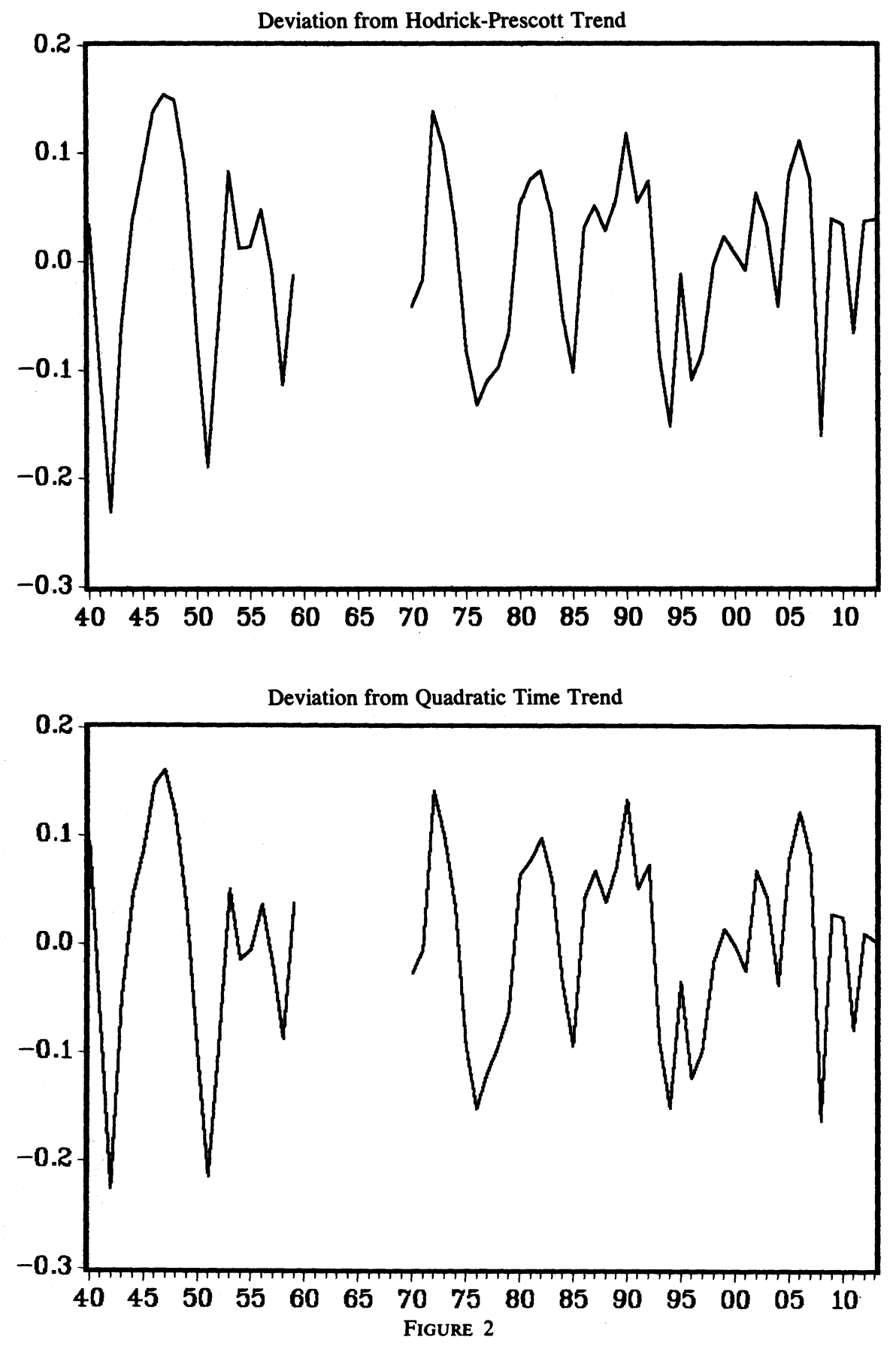

ANTEBELLUM-POSTBELLUM INDICES, 1840-1859 AND 1870-1913

$R$-squareds from the regressions. In either case the set of consistent series can predict more than 91 percent of the variation in deviation from trend in the Frickey index. To check that the relation is stable 
within the postbellum period, we regressed the Frickey index on the antebellum-postbellum indices in two subsamples from the postbellum period and observed the $R$-squareds shown in Table 3. The relation appears quite stable from 1870 to 1890 and 1891 to 1914 , so it may have been stable into the antebellum period as well.

What about the change from the antebellum to the postbellum period in the overall volatility of output? (Note that the antebellum index must be compared with the postbellum index constructed in the same way rather than with the Frickey index.) Figure 2 shows the series over both periods. Neither appears more volatile in the postbellum period. The second part of Table 3 confirms this judgment: the standard deviation of either series is smaller in the postbellum period.

\section{CONCLUSION}

The set of consistent antebellum-postbellum series clearly indicates that cyclical movements in industrial production were no larger, and were probably smaller, in the postbellum period than in the last two decades of the antebellum period. The cyclical volatility of GNP could nonetheless have been greater in the postbellum period, only because the share of cyclical sectors in aggregate output had grown relative to the share of acyclical agriculture. Would that constitute an increase in the severity of business cycles?

\section{Appendix}

Series (source) starting year:

Bituminous coal production, 1,000 tons (Eavenson, The First Century, pp. 426-434), 1800. These and the anthracite data are from many sources of different kinds. The numbers seem to be much better in the later antebellum decades (1840s and 1850s).

Pennsylvania anthracite coal production, 1,000 short tons (ibid., pp. 426-434) 1808.

Lead production from domestic and foreign ores, short tons (U.S. Bureau of Mines, "Summarized Data", pp. 12-14), 1821.

New York State Canal Tonnage, All and Erie only (U.S. Bureau of the Census, Historical Statistics, Q556, Q557), 1837.

Cotton consumption (U.S. Department of Commerce, Cotton Production, p. 57), 1826.

Pig iron production, thousand gross tons (1840-1853, Fogel, Railroads, p. 166; 1854-1914, American Iron and Steel Association, Annual Statistical Report 1917), 1840.

Coffee and tea imports (U.S. Department of the Treasury, Monthly Summary; U.S. Department of Commerce, Statistical Abstract 1907, 1917), 1821. 


\section{REFERENCES}

American Iron and Steel Association, Annual Statistical Report for 1895, 1896 (Philadelphia, 1896, 1897); 1917 (New York, 1917).

Balke, Nathan S., and Robert J. Gordon, "The Estimation of Prewar Gross National Product: Methodology and New Evidence," Journal of Political Economy, 97 (Feb. 1989), pp. 38-92.

Berry, Thomas Senior, "Estimated Annual Variations in Gross National Product, 1789 to 1909," Bostwick Paper No. 1 (Richmond, VA, 1968).

Berry, Thomas Senior, "Production and Population Since 1789, Revised GNP Series in Constant Dollars," Bostwick Paper No. 6 (Richmond, VA, 1988).

Burns, Arthur F., "Mitchell on What Happens During Business Cycles," in Conference on Business Cycles (New York, 1951), pp. 3-33.

Chandler, Alfred D., The Visible Hand: The Managerial Revolution in American Business (Cambridge, MA, 1977).

DeLong, J. Bradford, and Lawrence H. Summers, "The Changing Cyclical Variability of Economic Activity in the United States," in Robert J. Gordon, ed., The American Business Cycle: Continuity and Change (Chicago, 1987).

Eavenson, Howard N., The First Century and a Quarter of American Coal Industry (Pittsburgh, 1942).

Fogel, Robert William, Railroads and American Economic Growth: Essays in Econometric History (Baltimore, 1964).

Frickey, Edwin, Economic Fluctuations in the United States (Cambridge, MA, 1942).

Frickey, Edwin, Production in the United States 1860-1914 (Cambridge, MA, 1947).

Gallman, Robert, "Commodity Output, 1839-1899," in Trends in the American Economy in the Nineteenth Century, Studies in Income and Wealth (New York, 1960), vol. 24, pp. 13-71.

Gallman, Robert, "Gross National Product in the United States, 1834-1909," in Output, Employment and Productivity in the United States after 1800, Studies in Income and Wealth (New York, 1966), vol. 30, pp. 3-90.

James, John, "Changes in Economic Instability in 19th-Century America," American Economic Review, 83 (Sept. 1993), pp. 710-731.

James, John, “The Stability of the 19th-Century Phillips Curve Relationship," Explorations in Economic History, 26 (Apr. 1989), pp. 117-134.

Kuznets, Simon, "Comment" on Joseph Schumpeter in Conference on Business Cycles (New York, 1951), pp. 155-162.

Kydland, Finn, and Edward Prescott, "Business Cycles: Real Facts and a Monetary Myth," Federal Reserve Bank of Minneapolis Quarterly Review, 14 (Spring 1990), pp. 3-18.

Lebergott, Stanley, "Labor Force and Employment, 1800-1960," in Output, Employment and Productivity in the United States after 1800, Studies in Income and Wealth (New York, 1966), vol. 30, pp. 116-210.

$\rightarrow$ Miron, Jeffrey A., and Christina D. Romer, "A New Monthly Index of Industrial Production, 1884-1940," Journal of Economic History, 50 (June 1990), pp. 321-332.

Mitchell, Wesley C., What Happens During Business Cycles: A Progress Report (New York, 1951).

Moore, Geoffrey H., and Victor Zarnowitz, "The Development and Role of the National Bureau of Economic Research's Business Cycle Chronologies," in Robert J. Gordon, ed., The American Business Cycle (Chicago, 1986), pp. 735-779.

$\rightarrow$ O'Brien, Anthony Patrick, "Factory Size, Economies of Scale, and the Great Merger Wave of 1898-1902," Journal of Economic History, 48 (Sept. 1988), pp. 639-649.

Romer, Christina, "Is the Stabilization of the Postwar Economy a Figment of the Data?" American Economic Review, 76 (June 1986), pp. 314-334. 
Romer, Christina, "The Prewar Business Cycle Reconsidered: New Estimates of Gross National Product 1869-1908," Journal of Political Economy, 97 (Feb. 1989), pp. 1-37.

Taussig, Frank William, A Tariff History of the United States (New York, 1931).

Taussig, Frank William, Some Aspects of the Tariff Question (Cambridge, 1931).

Temin, Peter, The Jacksonian Economy (New York, 1969).

Towne, Marvin W., and Wayne D. Rasmussen, "Farm Gross Product and Gross Investment in the Nineteenth Century," in Trends in the American Economy in the Nineteenth Century, Studies in Income and Wealth (New York, 1960), vol. 24, pp. 255-315.

U.S. Bureau of Mines, Economic Paper Number 5, "Summarized Data of Lead Production,"' by L. A. Smith, 1929.

U.S. Council of Economic Advisers, Economic Report of the President (Washington, DC, various years).

U.S. Department of Agriculture, Bureau of Agricultural Economics, "The Agricultural Situation,' 19 (Jan. 1935).

U.S. Department of Commerce, Statistical Abstract of the United States, 1907, 1915, 1917 (Washington, DC, 1908, 1916, 1918).

U.S. Department of Commerce, Bureau of the Census, Bulletin 166, Cotton Production and Distribution, Season of 1928-1929 (Washington, DC, 1929).

U.S. Department of Commerce, Bureau of the Census, Historical Statistics of the United States (Washington, DC, 1975).

U.S. Department of Labor, Bureau of Labor Statistics, Employment, Hours and Earnings, United States, 1909-90 (Washington, DC, 1991).

U.S. Department of the Treasury, Bureau of Statistics, Monthly Summary of Finance and Commerce of the United States (Oct. 1896). 